\title{
Hard work takes you where luck can find you
}

\section{Leila Rouhi}

Center for Cardiovascular Genetics, Institute of Molecular Medicine and Department of Medicine, University of Texas Health Sciences Center at Houston, Houston, TX 77030, USA.

Correspondence to: Dr. Leila Rouhi, Center for Cardiovascular Genetics, Institute of Molecular Medicine and Department of Medicine, University of Texas Health Sciences Center at Houston, 6770 Bertner Street Suite C950H, Houston, TX 77030, USA. E-mail: Leila.Rouhi@uth.tmc.edu

How to cite this article: Rouhi L. Hard work takes you where luck can find you. J Cardiovasc Aging 2021;1:6. http://dx.doi.org/10.20517/jca.2021.03

Received: 13 May 2021 Accepted: 20 May 2021 Available online: 6 Jun 2021

Academic Editor: Marian AJ Copy Editor: Yue-Yue Zhang Production Editor: Yue-Yue Zhang

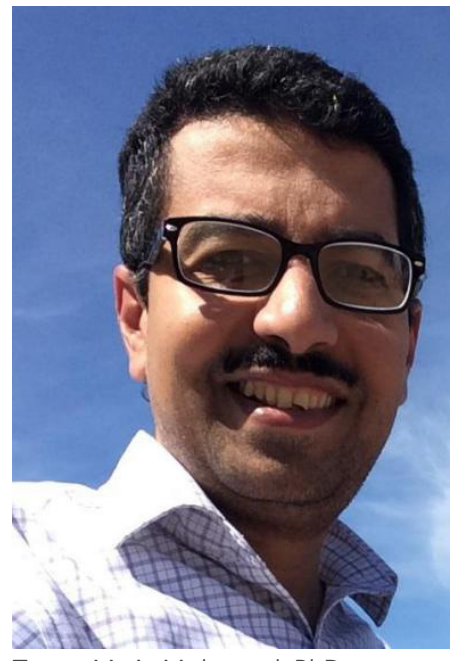

Tamer M. A. Mohamed, PhD.

Dr. Tamer Mohamed is an assistant professor at the University of Louisville, Kentucky, USA. As a teenager, he loved pharmacy and worked at his uncle's pharmacy during summer school breaks. The experience enticed him to study pharmacy in college, where he developed interest in science behind the medicines on pharmacy's shelves. "I loved to do discoveries for new medicines" as Dr. Mohamed said. As the top graduate of his class, his hard work granted him a master's degree in Biochemistry followed by a PhD degree at the

cc) (i) The Author(s) 2021. Open Access This article is licensed under a Creative Commons Attribution 4.0 International License (https://creativecommons.org/licenses/by/4.0/), which permits unrestricted use, sharing, adaptation, distribution and reproduction in any medium or format, for any purpose, even commercially, as long as you give appropriate credit to the original author(s) and the source, provide a link to the Creative Commons license, and indicate if changes were made. 
University of Manchester, England, all supported by the Egyptian government scholarship. He studied the effect of the plasma membrane calcium ATPase pumps on cardiac signaling and hypertrophy for his $\mathrm{PhD}$ thesis. His work was published in Nature Communication, JBC and Circulation. Tamer's outstanding achievements and productivity during his $\mathrm{PhD}$ training led to his recruitment as a postdoctoral fellow to the J David Gladstone Research Institutes (Cardiovascular), University of California, San Francisco. He was passionate to work on cardiac regeneration especially direct cardiac reprogramming and induction of cardiomyocyte proliferation. This work has formed the nucleus for the start-up company where he was one of the first scientists recruited. His transition to industry in Tenaya Therapeutics gave him the opportunity to experience the differences on how science is generated in industry compared to academia. In spite of a successful time spent in industry for two years, he eventually decided to return to academia and pursue new innovative research. He shared some of the key aspects of his personal life that have been inspiring as well as important to his success, three years after he started his own well-funded and well publishing laboratory.

\section{What experiences inspired you to become a cardiovascular scientist?}

My master's thesis was basically when it started getting me interested in the heart, because it was on "How to improve cardiac toxicity of Doxorubicin by phosphodiesterase inhibitors type 4". This allowed me to carry out my $\mathrm{PhD}$ in the cardiac field where I mainly focused on understanding the role of calcium signaling in cardiac hypertrophy. Then, when I was training as a $\mathrm{PhD}$ candidate, my mom had a heart attack. She is fine now. The experience made me more interested in delving into cardiac regeneration field to tackle ischemic heart failure.

Is there a particular scientist, or person that inspired you to pursue cardiovascular research? I have been lucky to have great mentors. Everybody can be hardworking but not everybody is lucky to have great mentors. My PhD mentor, Dr. Ludwig Neyses was very supportive, without him I wouldn't have achieved so much. Dr. Deepak Srivastava was very supportive when I was moving to the company and later when I was moving for my independent career. Even now he is very supportive and we are collaborating. Dr. Bolli has been very supportive here in Louisville and UofL. Having all the great mentors is the key to success.

\section{What habits have you established in your day-to-day life that you believe contribute to your success?}

I'm an early person. I wake up every morning at $\sim 5$ am and I stay at work until 6 or $7 \mathrm{pm}$ but then, I sleep at $10 \mathrm{pm}$. Therefore, I can still sleep for 7-8 h. I just shift the time. I’m more active in the morning. I get a lot done by the time other people come to the lab. The other habit is that I try to be very collaborative and work with others to provide help and advice for people. Sometimes people don't like collaboration and you need to deal with them. Research cannot be done by only one person and needs different expertise and collaboration to get full answers to the research questions.

\section{If you could go back in time, what is one piece of advice you would give your younger self when you started pursuing research?}

I keep thinking whether my decision to go to industry was right or not, although, at the end it turned out well for me and I learned a lot from it. I think my career path that I went to industry and returned to academia, is a rare career path and not many people would do that. The major challenge after going to industry is coming back to academia. I didn't stay there too long and did research most of the time, which is why I didn't have difficulty returning. Since they don't publish in companies very much (everything is kept as patent and so on), if you lose your publications track, it is hard to go back to academia. 
Tell us more about your experience in industry?

The speed of discoveries in industry is the speed of light because time is money. Therefore, you need to meet a lot of deadlines. You need to plan your experiments to give go- or no-go decisions. Industry has got great scientists and great minds. Thus, it is interesting and has got lots of things to learn but the mindset is different. What is interesting and what is not interesting is different in academia from industry. In academia you usually search for new discoveries but in industry, you are looking to apply these discoveries to humans.

\section{Do you have any advice for young trainees starting out in this field?}

Go for your passion and believe that you can do it because this job is really hard. We work 60-70 h per week, with nobody working $40 \mathrm{~h}$. It is very demanding and if you believe you can do it and have passion for it, you will do it.

How do you deal with setbacks in your research pursuits? Could you give an example of a time when you experienced challenges in research and resolved them?

There are a lot of setbacks. You try ten times and one will work. You can talk about experiments, a paper or a grant application. When I have a setback, I try to forget about it for some time. So, I go home, and I give it some time to avoid emotional decisions. Then, I try to think constructively. I do not think about what did not work but more on how to make it work or even when you hit the wall, how to go around this wall. This happens for every paper or every grant. I have never had a paper accepted from the first go. This career is full of setbacks but when you succeed, enjoy it to the fullest because it happens once out of ten tries.

\section{What is your proudest moment in your research career?}

It hasn't come yet. I think my proudest moment will be when something that I developed, is being used by people. I think Tenaya Therapeutics is in the way to this and I'm very looking forward to this moment. This will be my proudest moment.

What are some activities or hobbies you enjoy outside of the laboratory?

I love soccer and basketball and I play with my 9-year-old son in the backyard.

Do you have any tips for balancing personal life with research? What advice would you give to young investigators raising a family while pursuing this career path?

My wife is a postdoc and we have three kids: fourteen, nine and four years old. So, life is pretty hard, but we have managed to keep the balance between both of us. My wife starts work very early at 5 am and she leaves at $3 \mathrm{pm}$. I take care of the kids in the morning, take them to school and get to work around 8-8:30 am. It is hard, but working hand in hand is the key to managing it. My wife is very supportive and it is one of the major reasons for my success and where we are now.

What are your personal and academic goals as you move forward in your career as a scientist? My academic goals are to develop as many new strategies as we can for people with heart failure as the first leading cause of death (before COVID19) and now is the second cause of death (after COVID19) and I hope I end up with a few therapies in the hand of people by the end of my career. My personal goals are to raise my kid and get them to their best interest and to have a great family life with them and with my future grandchildren.

Are there any books, podcasts, or other forms of media that you recommend for young investigators to develop their mindset and prepare them for a career as a scientist?

I love Ted Talks. You can learn about different topics. I love history and I read a lot of books about history. My intuition is that the history repeats itself a lot and we should learn from history. We should 
see beyond the events that happened to see what led to the event and how to repeat good things and avoid bad things to happen again. I also encourage young investigators to read about emotional intelligence and management and how to lead by example.

\section{DECLARATIONS}

Authors' contributions

The author contributed solely to the article.

\section{Availability of data and materials}

Not applicable.

\section{Financial support and sponsorship}

None.

\section{Conflicts of interest}

The author declared that there are no conflicts of interest.

\section{Ethical approval and consent to participate}

Not applicable.

\section{Consent for publication}

Not applicable.

\section{Copyright}

(c) The Author(s) 2021. 